\title{
Determinants of Women Business Survival: A Study Among MSE's in East Gojjam Zone Administration; Ethiopia
}

\author{
Dereje Melaku Neway \\ PO box 269, Debre Markos University, Ethiopia \\ Department of Management, College of Business and Economics, Debre Markos University, Ethiopia
}

\begin{abstract}
Nowadays the micro and small scale enterprise survival factors are becoming prevailing issues. Objective of the study is to identify the determinants of women entrepreneurs' business survival in East Gojjam Zone Administration. In this study, both qualitative and quantitative types of data were used. The research design that was used in this study is Retrospective research design. From the total population of 73, sample size of 259 has been selected by using Yamane (1967) formula. In this study, Cox Proportional Hazards Model has been utilized to identify business survival factors. The study revealed that mainly form of business ownership, entrepreneurship training, ability to exploit opportunity, need for achievement, motivation to run business, access to credit finance, market linkage, customer handling skill and developing business plan before starting business have an effect on women MSE's survival.
\end{abstract}

Keywords: Entrepreneur, Survival, Retrospective

DOI: $10.7176 / \mathrm{EJBM} / 11-7-07$

Publication date:March $31^{\text {st }} 2019$

\section{Introduction}

Micro and Small Enterprises (MSEs) are a policy priority for many countries, given their significance in terms of it play a key role in economic development and make an important contribution to employment. There is a broad consensus that a vibrant MSE's sector is one of the principal driving forces in the development of a market economy and vital for a healthy economy (Nafukho and Muya, 2010).

Research indicates that Micro and Small Enterprises (MSE's) tend to have a lower survival rate as compared to large organizations, although they are commonly perceived as an engine of a country's economy (Bloch \& Bhattacharya, 2016; Lo, Wang, Wah, \&Ramayah, 2016). Many failure stories of MSEs reveal that their characteristics which include reactive, fire-fighting mentality, resource limitations, informal strategies, flexible structures, and lack of strategic planning processes may have contributed to their failures (Gnizy, Baker, \& Grinstein, 2014). The MSEs' survival factors have captured the interest of many scholars and practitioners (Onkelinx, Manolova, \& Edelman, 2015; Khalique, Bontis, Shaari, \& Md. Isa, 2015; Javalgi\& Todd, 2011). Studies conducted by Onkelinx et al. (2015) reveal that business performance of a small firm is driven by entrepreneurial orientation, which is affected by the national culture and environment. Khalique et al. (2015) illustrate that human capital does not play a significant role in determining organizational performance in the Pakistani context.

In Ethiopia the government gave special attention to Micro and Small Enterprise (MSE) development sector for the last decades. In 1998 the government formulated MSE development strategy and to implement the strategy the federal MSE trade works development agency was formed based on the establishment regulation number 33/1990 and later in 2004 based on the revised regulation number 104/1996 the agency was reformed and working hard to surmount its responsibility.

Based on the agency's establishment regulation number 33/1990 article 6 the government gave to the agency authorities and duties to identify training needs and give training for trainers at the center level, support and encourage establishment of vocational show room centers in different regions, promote and develop MSE trade works, select suitable technology, and create work relationship with concerned research institutions to conduct relevant technology based research and disseminate the result to the users.

In 2004 based on the revised regulation number 104/1996 the agency formed Technical, Vocational and enterprise development offices in regional and zonal level. The new strategy was formulated taking in to consideration that MSE's development should take the lion share in poverty reduction, improving the sectors development contributes a lot for the country economic growth; especially the sector creates sustainable employment opportunity for citizen and helps them in economic empowerment, and organizing youth in MSE development helping them to create their own job. Even though the office provides different services to MSE's, after sometimes problems related with business failure were manifested.

It is, therefore, necessary to investigate what factors influence women business survival and how to enhance the survival rate. Thus, the main aim of this paper is to identify the determinants of women entrepreneurs MSE's survival in East Gojjam Zone. 


\section{Statement of the Problem}

Entrepreneurship has becomes an important element for growth and development of most countries, especially after the financial crisis and economic downturn (Sowmya et al., 2010). Entrepreneurship is also claimed as the major driver of economy in the developed and developing countries (Ramadani et al., 2015; Hisrich et al., 2006). It is also reported that entrepreneurship curriculum area is growing rapidly in business schools around the world. This indicates that a lot of countries have emphasized and promoted entrepreneurship to support their economy. The opportunity to create profit and being their own employer has attracted many people to be entrepreneurs (Rose et al., 2006).

It is claimed that females view on their businesses are totally different from the way male do (Teoh and Chong, 2008). Some researchers claim that female entrepreneurs aim to achieve their intrinsic goals rather than maximizing the profit, they tend to perform less well on quantitative measures such as job creation, sales turnover and profitability. Some argue that these are due to the challenges that females have to go through in running the businesses. Thus, this study attempts to explore some of these challenges and their motivation factors.

In 2004 East Gojjam Zone Technical, Vocational and enterprise development office was formed. When we see the five year data of East Gojjam Zone, 732 Women owned Micro and Small Enterprises registered in 2012. The number of MSE's registered in 2013, 2014, 2015 and 2016 are 1079, 2068, 2352 and 2544 respectively. However, starting from 2012 to 2016 in five years 1349 women owned MSE's failed. Because of this a number of employees lost their job.

Hence, the aim of this research is to identify the determinants of women MSE's survival in Micro and small enterprises in East Gojjam zone.

\section{Objective of the Study}

The objective of this study is to identify the determinants of women entrepreneurs' business survival in East Gojjam Zone Administration, Amhara Regional state, Ethiopia.

\section{Review of Related Literature Concepts of Entrepreneurship}

Micro and Small Enterprises (MSE's) are a policy priority for many countries, given their significance in terms of it play a key role in economic development and make an important contribution to employment (Harash et al. 2014). There is a broad consensus that a vibrant MSE's sector is one of the principal driving forces in the development of a market economy and vital for a healthy economy (Nafukho and Muya, 2010). The men and women who run these enterprises are called Entrepreneurs. Entrepreneurship is a company that undertakes new arrangement to produce new products and services. It is a process of innovation and creation with four dimensional elements -individual, organization, environmental factors and process, with support from the government, education, and constitution (Kuratko and Hodgetts, 2004). Historically, it is proven that with each economic downturn in both developed and developing countries, it is the entrepreneurial drive and persistence that brings us back (Kuratko 2006). In this study, we focus on entrepreneurship as it takes place in MSE's since the two are closely related and cannot be isolated from each other.

Various types of MSE's such as village handicraft makers (weaving, embroidery etc), potteries, dying, small machine shops, restaurants, knitting, small dairy process etc, are, therefore, becoming increasingly important to economic development of developing nations. For example between 1990 and 1995, an average of 84 out of 100 new jobs in the region was generated by micro enterprises in Latin American countries (Orlando and Pollock, 2000). In Least Developed Countries (LDCs) in Asia Micro and small enterprises account for $80 \%$ of the firms generating $80 \%$ employment and $40-70 \%$ of value added and in Bangladesh Micro and small enterprises account for the majority of firms (87\%) providing $80 \%$ of total employment and contributing 15 percent to Gross Domestic Product (GDP) of the country (Narain, 2003).

\section{Women MSE's Business Survival}

Research indicates that Micro and Small Enterprises (MSE's) tend to have a lower survival rate as compared to large organizations, although they are commonly perceived as an engine of a country's economy (Bloch \& Bhattacharya, 2016; Lo, Wang, Wah, \&Ramayah, 2016). Many failure stories of MSE's reveal that their characteristics which include reactive, fire-fighting mentality, resource limitations, informal strategies, flexible structures, and lack of strategic planning processes may have contributed to their failures (Gnizy, Baker, \& Grinstein, 2014).

The MSEs' survival factors have captured the interest of many scholars and practitioners (Onkelinx, Manolova, \& Edelman, 2015; Khalique, Bontis, Shaari, \& Md. Isa, 2015; Javalgi\& Todd, 2011). Studies conducted by Onkelinx et al. (2015) reveal that business performance of a small firm is driven by entrepreneurial orientation, which is affected by the national culture and environment. Khalique et al. (2015) illustrate that human capital does not play a significant role in determining organizational performance in the Pakistani context. While human capital is generally understood as important antecedent factor in other related studies. Khalique et al. (2015) explain that 
being a developing economy, investment in training and development among Pakistani small businesses is woefully underrepresented, leading to inconsistent result. These existing studies demonstrate that firms in different context may react differently due to distinct economic and environment setting.

\section{Survival Strategy of MSE's}

Researchers argue that a person's early socialization can significantly affect that person's level of confidence, achievement, motivation and even ability to take risk. A gendered conclusion arrived at is that patriarchy negatively affects women's self-confidence, attitude towards success, and achievement motivation. Differences between male entrepreneurs and female entrepreneurs have been found in respect to skill and background characteristics, especially in education and work business experience (Smith-Hunter, 2006). The entrepreneurship process construct helped define the individuals investigated in this study in which an entrepreneur has been taken to be someone who has started or purchased a small business, and is still leading the business she started or purchased as in the Becherer and Maurer (1997) study. In many countries successful female entrepreneurship is seen as a positive but rare phenomenon. It therefore makes sense to develop a deeper understanding of these role models with a view to benefitting from what they have to offer. With the many issues cited by researchers about women entrepreneurs how some women have managed to achieve success is an area of research interest.

Awareness of women entrepreneurs' vital contribution to the economy has led to a number of studies looking at women's entrepreneurial ventures. There is a general agreement among entrepreneurship researchers that, relative to men, women entrepreneurs travel a tougher road to success (Smith-Hunter 2006). This has resulted in recommendations about the issues to be addressed in developing female entrepreneurship. To this extent a range of female entrepreneurship development models have been proposed. Most of these initiatives have focused on helping women to start up their own businesses and have considered the barriers women face (Bennet and Richardson, 2005). Recent research shows 40 to 50 percent of enterprises in developing countries are owned and run by women (Schlein, 2008). Surveys of micro and small businesses show a high participation of women in business in Zimbabwe (McPherson, 1998). This makes female entrepreneurs important participants in Zimbabwe's small business sector. Despite the high growth in the number of female owned businesses and their impact on society and the economy there are few studies researching female business owners (Brush, 1992). Most of the research on female entrepreneurship that has been done was conducted in developed countries and very little research has been carried out in developing countries, (Lerner, et al., 1997). The few reports on African women entrepreneurs highlight the predicament of these entrepreneurs, (Smith-Hunter, 2006). Many women who venture into the so-called man's world often find their way blocked by discrimination and laws that are stacked against them.

In Africa failure of economic structures to provide viable sources of income for women often causes them to embrace the world of entrepreneurship, thus relying on their own initiatives to develop a business enterprise (Radhakishim, C. 2000). Far less is known about the specific group of women who are formalizing and growing their businesses beyond survival level.

Zimbabwe is unique in the African region in that it has been experiencing significant structural changes in its economy. Women in Zimbabwe are an interesting group to study. Firstly, systemic prejudice and discriminatory laws, policies, financial constraints, years of neglect social-culturally, educationally and legislatively have severely handicapped women in terms of business and technical skills, access to resources and vital information relating to business. Secondly, their status has been changing with adjustments to socio-cultural and legislative practices. Thirdly, Zimbabwean women have demonstrated an unusually high involvement in small businesses. But there is no comprehensive information on how these women operate their businesses. Although there have been some studies of small businesses in Zimbabwe, none has provided rich qualitative data of female entrepreneurs.

Gartner (1988) defines entrepreneurship as the creation of new ventures, and the entrepreneurs as the creators of new ventures. At the centre of the entrepreneurial process, is the person who is influenced by the context in which the process takes place. In his model for new venture creation, Gartner (1985) argues that the entrepreneurial process is a complex and multidimensional phenomenon. Individuals with expertise are a key element of the new venture, the new venture is an organizational entity and the new venture is not instantaneously produced, but evolves over time. The new venture is seen in the context of its environment from where it seeks its resources and in which it competes in the marketplace. Entrepreneurship research suggests some generic characteristics and behaviors of entrepreneurs, (Anthony and Horne, 2007). Entrepreneurial behavior is seen as a function of some environmental factors (Baker and Nelson, 2005). Entrepreneur behaviors and decisions are a function of the entrepreneur's skills, experience, and values, and the environment in which the firm is operating. In studying management practice in small firms, the role of the entrepreneur is critical. Today, women in advanced market economies are said to own more than 25 percent of all businesses, with women-owned businesses in Africa, Asia, Eastern Europe and Latin America growing rapidly (Moghadam, 2005).

Overall, the global literature provides mounting evidence that business ownership by women is on the rise and is a vibrant and growing trend worldwide (Weiks and Seiler, 2001). Dismal economic conditions, high unemployment rates, spikes in divorce rates and the number of unmarried women, as well as the perpetual 
discrimination against women in the mainstream labor market are propelling women into alternative employment opportunities - such as the field of entrepreneurship (Riethof, 2004).

Women entrepreneurs are not a homogenous group, even when the analysis takes place while keeping geographical context constant, that is - looking at a particular country. That homogeneity is further shattered when the analysis is done across countries. Cultural and social patterns prescribe the characteristics of women entrepreneurs worldwide. Women entrepreneurs worldwide are shown to be mainly concentrated in the services industry, are on average between 40-45 years old, married with approximately 2-3 children, have primarily a college education, have been in business for approximately 10-15 years and have 10-20 employees (Smith-Hunter, 2006). Obstacles that women entrepreneurs face worldwide include: a lack of financial capital, inadequate human capital potential, lack of adequate network structures, especially one lacking in access to international networks and stifling government policies (Bitler et al, 2001). Creating educational tactics for improving women's human capital potential is fundamental for entrepreneurial growth and an essential component for producing an able crop of women who can enter and survive in the entrepreneurial word. Finally, access to financial capital is seen as a major criterion for this previously mentioned entrance and survival.

The connection to an international network structure is a necessary ingredient for women entrepreneurs to grow and prosper as legitimate concerns that must now compete in the global marketplace on an individual level, business ownership provides women with the financial dependence that offers numerous tangential opportunities. On a national level, having approximately fifty percent of any nation's economy earning an income is said to be critical to the prosperity of a country's economy. On a global level, having an increased number of women working will serve to change the face of world economies today, whether the work is taking place in the mainstream labor market or in entrepreneurial ventures. One approach that has been used to help small businesses grow proposes a combination of at least four necessary ingredients: motivation, abilities, ideas, and resources (Bennet and Richardson, 2005).

\section{Conceptual Frame work}

The conceptual frame work is developed based on the evidence available in literature. The following figure establishes the relationship between independent variables and business survival as a dependent variable.

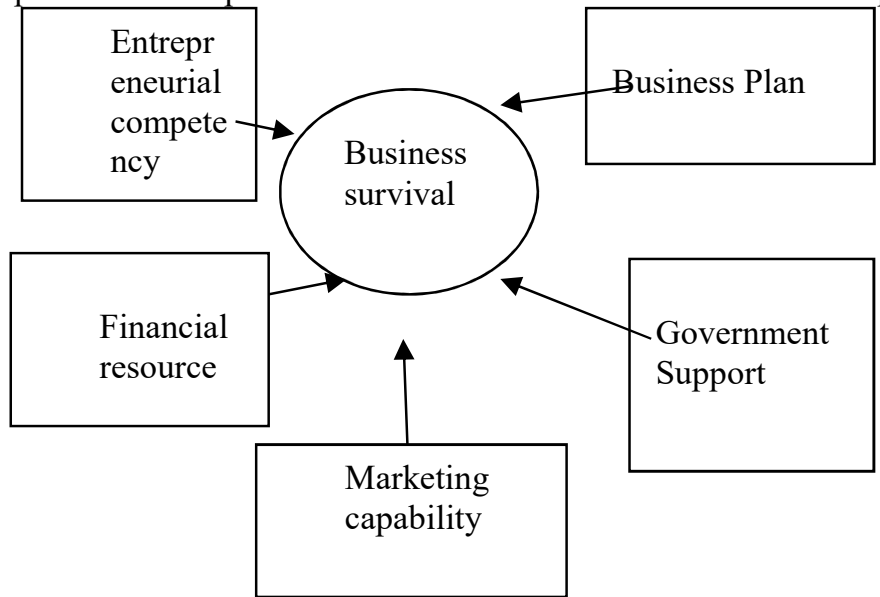

Figure 1. Conceptual frame work of the study

\section{Research Methodology}

To conduct this study, the researchers used both qualitative and quantitative types of data. In addition to this, to generate valuable and relevant data, the researchers collected data from both primary and secondary sources. Quantitative approach was applied to examine, through statistical procedures, the primary data which was collected from sample respondents by means of closed-ended questionnaire. Qualitative approach was applied to analyze the data that was collected by means of semi- structured interview. The research design that was used in this study is Retrospective research design.

The target population of this study is registered MSE's owned by women entrepreneurs that started business operation in 2012 in East Gojjam zone. The population includes the business that was survived and failed to operate up to August 2016. The total number of MSE's owned by women that formally registered in 2012 is 732 . This study apply a simplified formula provided by Yamane (1967) in order to determine the required sample size at $95 \%$ confidence level and with the level of precision of $=5 \%$ is,

$$
\mathrm{n}=\frac{\mathrm{N}}{1+\mathrm{N}(\mathrm{e})} 2
$$


Where $\mathrm{n}$ is the sample size, $\mathrm{N}$ is the population size, and e is the level of precision.

$$
\mathrm{n}=\frac{732}{1+732(0.05)} 2,
$$

The researchers classified total sample size in to MSE's survived and closed based on 1:5 ratio by taking into consideration the assumption of Cox proportional hazards model. Therefore, 207 respondents from survived MSE's owned by women entrepreneurs and 52 respondents from closed MSEs owned by women entrepreneurs were selected as a sample. In addition to this, the researchers distributed the total sample size proportionally to selected Woredas/Town Administrations. In this study cluster sampling was used. Data collection were done using questionnaires and interview with woredas technical, vocational and enterprise development office heads and East Gojjam zone technical, vocational and enterprise development office experts. Secondary data such as annual report of the office, training manuals, and business plan format were revised.

\section{Model of the Research}

Survival factors more identified through Cox Proportional Hazards Model. One measure of survival analysis utilized, where the MSE's are either survived or failed in July 2016. The dependent variable business survival which assumes " 1 " if the women MSE's are survived and " 0 " if the women MSE's are failed. The purpose of the model is to evaluate simultaneously the effect of several factors on women MSE business survival. In other words, it allows us to examine how specified factors influence the rate of failure in five years. This rate is commonly referred as the hazard rate. Predictor variables (factors) are usually termed covariates in the survival analysis literature.

The Cox model is expressed by the hazard function denoted by $h(t)$. Briefly, the hazard function can be interpreted as the risk of MSE's failure at time $t$. It can be estimated as follow:

$\mathrm{h}(\mathrm{t})=\mathrm{h} 0(\mathrm{t}) * \exp \left(\beta_{1} \mathrm{x}_{1}+\beta_{2} \mathrm{x}_{2}+\beta_{3} \mathrm{x}_{3}+\beta_{4} \mathrm{x}_{4}+\beta_{5} \mathrm{x}_{5}\right)$

Where,

- $\quad t$ represents the survival time

- $\mathrm{h}(\mathrm{t})$ is the hazard function determined by covariates $\left(\mathrm{x}_{1}, \mathrm{x}_{2}, \mathrm{x}_{3}, \mathrm{x}_{4}, \mathrm{x}_{5}\right)$

- the coefficients $\left(\beta_{1}, \beta_{2}, \beta_{3}, \beta_{4}, \beta_{5}\right)$ measure the impact (the effect size) of covariates

- A positive sign means that the hazard (risk of business failure) is higher

- A negative sign means that the hazard (risk of business failure) is lower

- ho is called the baseline hazard. It corresponds to the value of the hazard if all the $\mathrm{x}_{i}$ are equal to zero (the quantity $\exp (0)$ equals 1$)$. The $t$ in the $h(t)$ reminds us that the hazard may vary over time.

- $\quad \exp \left(\beta_{\mathrm{i}}\right)$ is called hazard ratio $(\mathrm{HR})$

$\mathrm{HR}=1$, No effect

$\mathrm{HR}<1$, Reduction in the hazard

$\mathrm{HR}>1$, Increase in hazard

- $\mathrm{x}_{1}$ represent entrepreneurial competency

- $\mathrm{x}_{2}$ represent financial resource

- $\mathrm{x}_{3}$ represent marketing capability

- $\mathrm{x}_{4}$ represent government support

- $\mathrm{x}_{5}$ represent business plan

\section{Result and Discussion}

The final results obtained in the study are presented and discussed in this part. Micro and Small Enterprises owned by women entrepreneur those started business operation in 2012 in East Gojjam Zone were considered as respondents for the questionnaires designed to measure determinants of women business survival. However, the study includes the Micro and Small Enterprises that was survived and failed to operate up to August 2016.

\section{Kaplan-Meier Survival Analysis}

The survival time of women entrepreneurs business is estimated based on variable entrepreneurship training by using Kaplan-Meier survival analysis model as shown below. The difference between the groups of trained and untrained women entrepreneurs when they establish business in survival time estimated by using Kaplan-Meier survival analysis model as shown in Table 3 below. 
Table 1. Case processing summary

\begin{tabular}{|c|c|c|c|c|}
\hline \multicolumn{5}{|c|}{ Case Processing Summary } \\
\hline \multirow[t]{2}{*}{ Did you take entrepreneurship training? } & \multirow[t]{2}{*}{ Total N } & \multirow[t]{2}{*}{$\mathrm{N}$ of Events } & \multicolumn{2}{|c|}{ Censored } \\
\hline & & & $\mathrm{N}$ & Percent \\
\hline No & 136 & 34 & 102 & $75.0 \%$ \\
\hline Yes & 122 & 18 & 104 & $85.2 \%$ \\
\hline Overall & 258 & 52 & 206 & $79.8 \%$ \\
\hline
\end{tabular}

Table 2. Overall comparisons

\begin{tabular}{|c|c|c|c|}
\hline \multicolumn{4}{|c|}{ Overall Comparisons } \\
\hline & Chi-Square & $\mathrm{df}$ & Sig. \\
\hline Log Rank (Mantel-Cox) & 4.034 & 1 & .045 \\
\hline
\end{tabular}

Table 3. Entrepreneurship Training

\begin{tabular}{|c|c|c|c|c|}
\hline \multirow[t]{3}{*}{ Entrepreneurship Training } & \multicolumn{4}{|c|}{ Mean for Survival Time } \\
\hline & \multirow[t]{2}{*}{ Estimate } & \multirow[t]{2}{*}{ Std. Error } & \multicolumn{2}{|c|}{$95 \%$ Confidence Interval } \\
\hline & & & Lower Bound & Upper Bound \\
\hline Untrained & 4.441 & .090 & 4.265 & 4.617 \\
\hline Trained & 4.648 & .084 & 4.484 & 4.811 \\
\hline Overall & 4.539 & .062 & 4.417 & 4.660 \\
\hline
\end{tabular}

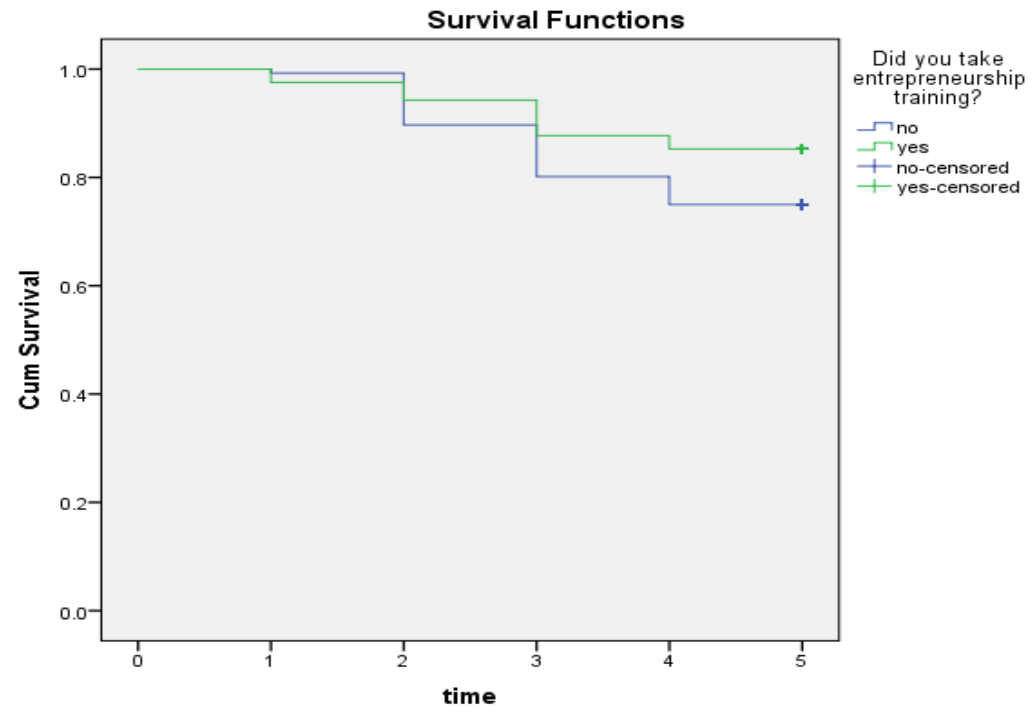

Figure 2. Survival functions

The difference between survival time of trained and untrained women entrepreneurs' when they establish business are estimated by using Kaplan-Meier survival analysis. The estimated mean survival time of business is 4.648 years for trained women entrepreneurs and 4.441 years for untrained women entrepreneurs. The log rank test result (figure 2) shows that there is significant evidence of difference in survival time between trained and untrained women entrepreneurs at 5\% level. Hence, trained women entrepreneurs have increased chance of survival. Moreover, the interview result with East Gojjam Zone Technical, vocational and Enterprise development office employees indicates that the training manuals are not well organized. Means they give trainings for women entrepreneurs they do not consider entrepreneurs age, educational background, sex, skill and experience. Trainers simply give the training for the trainees together in one place, the same topic without differentiating their level of understanding. However, keeping all these things in mind the estimated mean survival time of trained women entrepreneurs are higher than untrained women entrepreneurs. This indicates that if the training prepared in well organized materials, offered by well trained trainers and according to their level of understanding the survival rate of women entrepreneurs business increase.

\section{Cox proportional hazard model}

In this section, Cox proportional hazard model is performed to identify what factors determines business survival. One measure of survival analysis utilized, where the business is either open or closed in August 2016. The dependent variable business survival which assumes " 1 " if the women MSEs" Business is open and " 0 " if the 
women MSEs’ Business is closed.

$$
h(t)\left\{\begin{array}{c}
1=\text { surived } \\
0=\text { closed }
\end{array}\right.
$$

Table 4. Cox proportional hazard model result

\begin{tabular}{|c|c|c|c|c|c|}
\hline & $\mathrm{B}$ & Sig. & $\operatorname{Exp}(B)$ & $95.0 \% \mathrm{CI}$ & $\operatorname{Exp}(B)$ \\
\hline & & & & Lower & Upper \\
\hline Age at the time of establishment & -.018 & .484 & .983 & .936 & 1.032 \\
\hline \begin{tabular}{|ll} 
Educ. & Illiterate \\
\end{tabular} & & .031 & & & \\
\hline Read and write & -2.307 & $.013 *$ & .100 & .016 & .609 \\
\hline Elementary school complete & -1.364 & .077 & .256 & .056 & 1.159 \\
\hline High school complete & -1.662 & $.031 *$ & .190 & .042 & .858 \\
\hline Certificate & -1.551 & $.047 *$ & .212 & .046 & .980 \\
\hline Diploma & -1.591 & $.047 *$ & .204 & .043 & .976 \\
\hline Degree & -.046 & .957 & .955 & .177 & 5.153 \\
\hline Sole proprietorship & & .049 & & & \\
\hline Partnership & 1.598 & $.018 *$ & 4.941 & 1.319 & 18.516 \\
\hline Cooperatives & .014 & .969 & 1.014 & .507 & 2.025 \\
\hline Entrepreneurship training & -.623 & $.044 *$ & .536 & .293 & .983 \\
\hline Willingness to take reasonable risk & .027 & .948 & 1.028 & .450 & 2.349 \\
\hline Ability to exploit opportunity & -.883 & $.018 *$ & .413 & .198 & .862 \\
\hline Self-confidence & .219 & .571 & 1.245 & .584 & 2.653 \\
\hline Need for achievement & -1.106 & $.005 *$ & .331 & .152 & .718 \\
\hline Motivation to run business & -1.089 & $.017 *$ & .337 & .138 & .822 \\
\hline Access to credit finance & -1.091 & $.032 *$ & .336 & .124 & .909 \\
\hline Financial management skill & -.978 & $.007 *$ & .376 & .186 & .761 \\
\hline Availability of adequate working capital & -.057 & .879 & .945 & .454 & 1.967 \\
\hline Proximity to customers & .661 & .105 & 1.936 & .872 & 4.300 \\
\hline Market linkage & -1.861 & $.000 *$ & .156 & .055 & .441 \\
\hline Fair competition in the market & .882 & .085 & 2.416 & .886 & 6.590 \\
\hline Customer handling skill & -1.156 & $.008 *$ & .315 & .134 & .740 \\
\hline Beneficiary from government business policy & .704 & .130 & 2.022 & .814 & 5.027 \\
\hline Developing business plan before starting business & -1.198 & $.004 *$ & .302 & .134 & .682 \\
\hline Developing business plan to solve problem & -.745 & .370 & .475 & .093 & 2.423 \\
\hline
\end{tabular}

*-Significant at 5\% level

\section{Omnibus Tests of Model Coefficients}

-2 Log Likelihood $=469.217$

Overall (score) Chi-square $=74.536$

$\mathrm{df}=25$

$$
\text { Sig. }=.000
$$

The omnibus tests of the model overall result in which the effect of covariates on women business survival show that the model is significant at 5\% level. In the Cox regress analysis, the covariates such as level of education at the time of establishment, form of business ownership, entrepreneurship training, ability to exploit opportunity, need for achievement, motivation to run business, access to credit finance, financial management skill, market linkage, customer handling skill and developing business plan before starting business are significant at $5 \%$ level. Therefore, these covariates are associated with better survival of women business.

\section{Reporting regression coefficient and hazard ratio}

For level of education at time of establishment, the reference category is illiterate women entrepreneurs group which means that all the other categories are compared to the group containing women entrepreneurs those are illiterates. There is evidence of significant difference between illiterates and, read and write group, at the p-value of 0.013 . The beta coefficient (B) for read and write (-2.307) indicates that women entrepreneurs those who can read and write have lower risk of failure than illiterate group. The hazard ratio $(0.100)$ indicates that, holding the other covariates constant, the basic skill of read and write reduces risk of failure by $(1-0.100 * 100)=90$ percent. In the same way, there is evidence of significant difference between illiterates and high school completes, at the $\mathrm{p}$-value of 0.031 . The beta coefficient (B) for high school completes (-1.662) indicates that women entrepreneurs those completed high school education have lower risk of failure than illiterates. The hazard ratio $(0.190)$ indicates that, holding the other covariates constant, completing high school education reduces the hazard of business failure by 81 percent.

Similarly, there is evidence of significant difference between illiterates and certificate program completes, at 
the p-value of 0.047 . The beta coefficient (B) for certificate program complete $(-1.551)$ indicates that women entrepreneurs those completed certificate program have lower risk of failure than illiterates. The hazard ratio $(0.212)$ indicates that, holding the other covariates constant, completing certificate program reduces the hazard of failure by 78.8 percent. Also, there is evidence of significant difference between illiterates and diploma program completes, at the p-value of 0.047 . The beta coefficient (B) for diploma program completes $(-1.591)$ indicates that women entrepreneurs those completed diploma program have lower risk of failure than illiterates. The hazard ratio (0.204) indicates that, holding the other covariates constant, completing certificate program reduces the hazard of failure by 79.6 percent.

By contrast, the p-value for elementary school completes (0.077) and degree (0.957) indicates that there is no significant evidence of greater difference in risk of failure. However, even if the difference is not significant, as depicted in Table 4.12 above the beta coefficient (B) and hazard ratio results show that when the level of education increases the hazard of business failure reduces.

Aimed at form of business ownership, the reference category is sole proprietorship form of ownership group which means that all the other categories are compared to the group containing women entrepreneurs those establish their business in sole proprietorship form. There is evidence of significant difference between sole proprietorship and partnership form of business group, at the p-value of 0.018 . The beta coefficient (B) for partnership form of ownership (1.598) indicates that women entrepreneurs those establish their business in partnership form have higher risk of failure than sole proprietorship form. The hazard ratio (4.941) indicates that, holding the other covariates constant, establishing business in partnership form increases the hazard of failure by 4.941 times. However, the cooperative form ( $p$-value of 0.969 ) indicates that there is no significant evidence of greater difference in risk of failure. Therefore, the hazard ratio 1.014 indicates that no significant evidence of greater difference in risk of failure.

For entrepreneurship training, there is evidence of significant difference between groups of trained and untrained women entrepreneurs at $p$-value of 0.044 . The beta coefficient (B) for entrepreneurship training $(-0.623)$ indicates that trained women entrepreneurs have lower risk of failure than untrained women entrepreneur. The hazard ratio (0.536) indicates that, holding the other covariates constant, taking entrepreneurship training reduces the hazard of failure by 46.4 percent.

Intended for ability to exploit opportunity, there is proof of significant difference between groups of women entrepreneur with ability to exploit opportunity and with no ability to exploit opportunity at p-value of 0.018 . The beta coefficient (B) for ability to exploit opportunity $(-0.883)$ indicates that women entrepreneur with ability to exploit opportunity have lower risk of failure than women entrepreneur with no ability to exploit opportunity. The hazard ratio (0.413) indicates that, holding the other covariates constant, having an ability to exploit opportunity reduces the hazard of failure by 58.7 percent.

For need for achievement, there is evidence of significant difference between groups of women entrepreneur those have high need for achievement and those do not have high need for achievement at p-value of 0.005 . The beta coefficient (B) for high need for achievement (-1.106) indicates that women entrepreneur those have high need for achievement have lower risk of failure than those do not have high need for achievement. The hazard ratio (0.331) indicates that, holding the other covariates constant, having high need for achievement reduces the hazard of failure by 66.9 percent.

Designed for motivation to run business, there is proof of significant difference between groups of women entrepreneur those have high motivation to run business and those do not have high motivation to run business at p-value of 0.017 . The beta coefficient (B) for high motivation to run business (-1.089) indicates that women entrepreneur those have high motivation to run business have lower risk of failure than those do not have high motivation to run business. The hazard ratio (0.337) indicates that, holding the other covariates constant, having high motivation to run business reduces the hazard of failure by 66.3 percent.

Meant for access to credit finance, there is verification of significant difference between groups of women entrepreneur those have access to credit finance and those do not have access to credit finance at $p$-value of 0.032 . The beta coefficient (B) for access to credit finance (-1.091) indicates that women entrepreneur those have access to credit finance have lower risk of failure than those do not have access to credit finance. The hazard ratio $(0.336)$ indicates that, holding the other covariates constant, having access to finance reduces the hazard of failure by 66.4 percent.

Intended for financial management skill, there is evidence of significant difference between groups of women entrepreneur those have good financial management skill and those do not have good financial management skill at p-value of 0.007 . The beta coefficient (B) for good financial management skill ( -0.978$)$ indicates that women entrepreneur those have good financial management skill have lower risk of failure than those do not have good financial management skill. The hazard ratio (0.376) indicates that, holding the other covariates constant, having good financial management skill reduces the hazard of failure by 62.4 percent.

For creating market linkage, there is proof of significant difference between groups of women entrepreneur those created market linkage and those do not created market linkage by themselves at $p$-value of 0.000 . The beta 
coefficient (B) for creating market linkage (-1.861) indicates that women entrepreneur those created market linkage have lower risk of failure than those do not created market linkage. The hazard ratio (0.156) indicates that, holding the other covariates constant, creating market linkage reduces the hazard of failure by 84.4 percent.

Designed for customer handling skill, there is evidence of significant difference between groups of women entrepreneur those have good customer handling skill and those do not have good customer handling skill at pvalue of 0.008 . The beta coefficient (B) for good customer handling skill (-1.156) indicates that women entrepreneur those have good customer handling skill have lower risk of failure than those do not have good customer handling skill. The hazard ratio (0.315) indicates that, holding the other covariates constant, having good customer handling skill reduces the hazard of failure by 68.5 percent.

Intended for developing business plan before starting business, there is proof of significant difference between groups of women entrepreneur those developed and not developed business plan before starting business at $p$ value of 0.004 . The beta coefficient (B) for developing business plan before starting business (-1.198) indicates that women entrepreneur those developed business plan before starting business have lower risk of failure than those do not developed before starting business. The hazard ratio (0.302) indicates that, holding the other covariates constant, developing business plan before starting business reduces risk of failure by 69.8 percent.

\section{Conclusions}

Entrepreneurial competencies such as ability to exploit opportunity, innovative ability, motivation to run business and vision to expand business are associated significantly with women entrepreneurs MSE's survival. Hence, improving women entrepreneurs entrepreneurial competency through continuous, well organized and according to their level training enhance women entrepreneurs MSE's survival.

Financial resources like access to credit finance, financial management skill, reasonable collateral security requested by lending institutions, reasonable interest rate charged by lending institutions, availability of adequate working capital and saving culture are associated significantly with women entrepreneurs MSE's survival. Thus, enhancing women entrepreneurs financial management skill and taking advantage of getting loan with low interest rate and minimum collateral security improve the survival rate of women entrepreneurs MSE's.

Marketing capability such as creating market linkage, the availability of good transport service, the existence of fair market competition and ability to search new market for products are associated significantly with women entrepreneurs MSE's survival. Consequently, by providing marketing training and consultancy in collaboration with professionals enhance the survival probability of women entrepreneurs MSE's.

Technology usage like access to use the necessary technology, affordability of new technology acquiring cost, skill to adopt technology and suitability of ICT tools to access market information are associated significantly with women entrepreneurs MSE's survival. As a result, providing necessary technology in affordable cost and enhancing women entrepreneur technology using skill through training improve the probability of women entrepreneurs MSE's survival.

Government support like being beneficiary from government business policy is significantly associated with women entrepreneurs MSE's survival. However, women entrepreneurs know how the government policy give priority for them, continues trainings are given for women entrepreneurs but still the result is not like expected. Hence, improving women entrepreneurs awareness towards properly using government support together with providing all support planed in proclamation by government officials enhance women entrepreneurs MSE's survival.

Preparing business plan during establishing business, preparing business plan to expand business and preparing business plan to solve problem are significantly associated with women entrepreneurs MSE's survival.

There is significant evidence of difference in survival time between trained and untrained women entrepreneurs. This means trained women entrepreneurs have increased chance of survival. Hence, if the training prepared in well organized materials, offered by well trained trainers and according to their level of understanding the survival rate of women entrepreneurs MSE's increase.

In the Cox proportional hazards regress analysis reveal that covariates such as level of education at the time of establishment, form of business ownership, entrepreneurship training, ability to exploit opportunity, need for achievement, motivation to run business, access to credit finance, financial management skill, market linkage, customer handling skill and developing business plan before starting business have an effect on women MSE's survival. Hence, these covariates are more likely to reduce the probability of women entrepreneurs MSE's failure rate.

\section{Reference}

Ahmad, H.N., Ramayah, T., Wilson, C., \&Kummerow, L. (2010). Is entrepreneurial competency and business success relationship contingent upon business environment? A study of Malaysian SMEs. International Journal of Entrepreneurial Behavior \& Research, 16(3), 182-203. https://doi. org/10.1108/13552551011042780. 
Anthony, D. \& Horne, C. (2003). Gender and corporation: Explaining loan repayment in microcredit groups. Social Psychology Quarterly, 66(3), 293-302.

Baker, T. \& Nelson, R. (2005).Creating something from nothing: Resource construction through entrepreneurial bricolage. Administrative Science Quarterly, 50, 325-366.

Becherer R. C. \& Maurer J. G. (1997).The moderating effect of environmental variables on the entrepreneurial and marketing orientation of entrepreneur-led firms. Entrepreneurship Theory and Practice, 22(1), 47-58.

Bennet D., \& Richardson, P. (2005). Building relationships and social capital for women's enterprise development: Research and practice from an award winning support initiative. Women Into Network (WIN), ICSB, 2005.

Bitler, M. P., Robb, A. M. \& J.D. Wolken (2001). Financial Services used by Small Businesses: Evidence from the 1998 Survey of Small Business Finances. Federal Reserve Bulletin, 87, 183205.

Bloch, H., \& Bhattacharya, M. (2016). Promotion of innovation and job growth in small and medium-sized enterprises in Australia: Evidence and policy issues. Australian Economic Review, 49(2), 192-199. https://doi.org/10.1111/1467-8462.12164.

Brush, C. G. (1992). Research on women business owners: Past trends, a new perspective and future directions. Entrepreneurship Theory and Practice, 16(4), 5-31.

Gartner, W. B. (1988). "Who is an entrepreneur?" Is the wrong question to ask. American Journal of Small Business, Spring, 1988, 11-32.

Gnizy, I., Baker, W.E., \& Grinstein, A. (2014). Proactive learning culture: A dynamic capability and key success factor for SMEs entering foreign markets. International Marketing Review, 31(5), 477-505. https://doi.org/10.1108/IMR-10-2013-0246.

Harash, E., Al-Tamimi, K., \& Al-Timimi, S. (2014). The Relationship between Government Policy and Financial Performance: A Study on the SMEs in Iraq. journal China-USA Business Review, Vol. 13, No. 4.

Hirsch, S., \&Schiefer, J. (2016). What causes firm profitability variation in the EU food industry? A redux of classical approaches of variance decomposition. Agribusiness, 32(1), 79-92. https://doi.org/10.1002/agr.21430.

Hisrich, R. D. \& Brush, C. G. (1986). The woman entrepreneur: Starting, financing and managing a successful new business, Lexington Books.

Hisrich, R.D., Bowser, K. Smarsh, L.S. (2006), Women entrepreneurs in the Ukraine. International Journal of Entrepreneurship and Small Business, 3(2), 207-221.

Javalgi, R.R.G., \& Todd, P.R. (2011). Entrepreneurial orientation, management commitment, and human capital: The internationalization of SMEs in India. Journal of Business Research, 64(9), 1004-1010. https://doi.org/10.1016/i.jbusres.2010.11.024.

Khalique, M., Bontis, N., Shaari, J.A.N., \& Md. Isa, A.H. (2015).Intellectual capital in small and medium enterprises in Pakistan. Journal of Intellectual Capital, 16(1), 224-238. https://doi.org/10.1108/JIC-01-2014$\underline{0014}$.

Kuratko,\&Hodgetts. (2004), Entrepreneurship: Theory and Practice. Thomson, Southwestern: New York.

Kuratko, D, (2006). A Tribute to 50 years of Excellence in Entrepreneurship and Small Business.Journal of Small Business Management, 44(3), 483-492 http://dx.doi.org/10.1111/j.1540-627X.2006.00185.x.

Lerner, M. \&Almor, T. (2002).Relationships among strategic capabilities and the performance of women-owned small ventures. Journal of Small Business Management, 40(2), 109-125.

Lo, M.C., Wang, Y.C., Wah, C.R.J., \&Ramayah, T. (2016). The critical success factors for organizational performance of SMEs in Malaysia: A partial least squares approach. RevistaBrasileira de Gestão de Negócios / Review of Business Management, 18(61), 370.https://doi.org/10.7819/rbgn.v18i61.3058.

McPherson, M. A. (1998). Zimbabwe: A Third Nationwide Survey of Micro and Small Enterprises, Growth and Equity through Microenterprise Investments and Institutions, USAID.

Moghadam, V. (2005). Globalizing Women: Transnational Feminist Networks, The John Hopkins University Press, Baltimore, MD.

Nafukho, M, \&Muya, H. (2010) Entrepreneurship and socio-economic development in Africa: a reality or myth? Journal of European Industrial Training, 34(2), 196-209. http://dx.doi.org/10.1108/03090591011023961.

Narain, S (2003). Institution Capacity Building for Small and Medium -Sized Enterprise Promotion and Development. Investment Promotion and Enterprise Development Bulletin for Asia and the Pacific, number \#2, U.N. May.

Orlando, M, \& Pollock, M. (2000). Micro Enterprises and Poverty: Evidence from Latin America. Inter-American Development Bank, Washington D.C.

Radachkishun, C (2000). Women entrepreneurs in least developed countries: Profile, Problems and policies, Section II in Women entrepreneurs in Africa: Experience from selected countries, New York and Geneva: United Nations Publications.

Ramadani, V., Hisrich, R.D., Gerguri, S. (2015), Female entrepreneurs in transition economies: Insights from Albania, Macedonia and Kosovo. World Review and Entrepreneurship, Management and Sustainable 
Development, 11(4), 391-413.

Riethof, M. (2004).Changing Strategies of the Brazilian labor Movement.Latin American Perspectives, 31(6), 31 47.

Rose, R.C., Kumar, N., Lim, L.Y. (2006), The dynamics of entrepreneurs success factors in influencing venture growth. Journal of Asia Entrepreneurship and Sustainability, 2(3), 1-19.

Schlein, L. (2008). Women Entrepreneurs succeed in developing countries. VOA news.com, August 31, 2008, Geneva.

Smith-Hunter, A. (2006). Women Entrepreneurs Across Racial Lines: Issues of Human Capital, Financial Capital and Network Structures, Edward Elgar Publishing, Cheltenham, UK and Lyme, US.

Sowmya, D.V., Majumdar, S., Gallant, M. (2010), Relevance of education for potential entrepreneurs: An international investigation. Journal of Small Business and Enterprise Development, 17(4), 626-640.

Teoh, W.M.Y., Chong, S.C. (2008), Improving women entrepreneurs in small and medium enterprises in Malaysia: Policy recommendations. Communication of IBIMA, 2, 31-38.

WeiJ. \& D. Seiler (2001). Women's Entrepreneurship in Latin America: An Exploration of Current Knowledge, Inter-American Development Bank. Sustainable Development Department Technical Papers Series, 331.48 W4457-dc21. 